\title{
Occupational hazards and their effect on the health and socio-economic status of local palm oil processors in Delta State, Nigeria
}

\author{
James Bamidele ${ }^{1}$ \\ ${ }^{1}$ Department of Community Medicine, College of Medicine, Ekiti State University, Ado-Ekiti, Nigeria \\ Bamidele J. Occupational hazards and their effect on the health and socio-economic status of local palm oil processors in Delta State, \\ Nigeria. Ann Agric Environ Med. 2015; 22(3): 483-487. doi: 10.5604/12321966.1167719
}

\begin{abstract}
Introduction and Objective. Nigerian rural farmers still use a crude method for farming. The objective of this study is to identify the hazards of traditional palm oil processing in the Ethiope West Community of Delta State, Nigeria, and the associated socio-economic and health consequences on the peasant farmers.

Materials and Methods. A cross-sectional analytical study was carried out among the rural palm oil processors. An interviewer administered questionnaire was issued to respondents who were selected using a multi-stage sampling method. Results. 295 respondents participated in the survey; male/female ratio - 4:1. 52.9\% had only primary or no formal education; and respondents had spent a median of 4.0 years (IQR: 2.0 to 7.0 ) in palm oil processing. Spikelet and burn injuries were the hazards faced by most respondents. Hand gloves (48.2\%), boots (23.7\%), protective wears (22.7\%) and helmets (5.4\%) were the personal protective equipment reported to be available. As many as $78.0 \%$ of respondents had experienced injury while at work, and $22.7 \%$ had fallen ill in the past twelve months prior to the study. Those who believed that the occupation was hazardous were about twice as likely to have experienced a work-related injury $-p>0.05$.

Conclusion. Rural palm oil processors in the study area are socio-economically poor. They suffer from occupational injuries and illnesses that are directly related to their occupational exposure.
\end{abstract}

Key words

traditional palm oil processing, occupational hazards, socio-economic status, health effect

\section{INTRODUCTION}

It is generally agreed that the oil palm originated in the tropical rain forest region of West Africa. The main belt runs through the southern latitudes of Cameroon Co'te d'Ivore, Ghana, Liberia, Sierra Leone, Togo and Congo [1, 2]. Oil palm is indigenous to the Nigerian coastal plain, having migrated inland as a stable crop [3]. The oil palm is one of the important economic crops in the tropics [4].

The palm oil is a versatile tree crop with almost all parts of the tree being useful and of economic value. The principal product of the oil palm is the palm fruit, which is processed to obtain three commercial products. These include palm oil, palm kernel oil and palm kernel cake. The oil palm tree grows up to 20 meter in height and grows best at temperature of $24-27^{\circ} \mathrm{C}$. It require a humid climate and the cultivated oil palm carry fruit from their fourth year onward and can be harvested for 40-50 years [5].

Crude palm oil (CPO) is obtained from the mesocarp part of the oil palm fruit after undergoing several processes, such as sterilization, stripping, extraction and purification. The oil palm produces two types of oils, palm oil from the fibrous mesocarp and palm kernel oil from the palm kernel. The uses of palm oil are many and varied [6]. Locally, it is used for cooking, ma king soap, metal plating and as lamp oil. The palm kernel oil, however, is used for ma king soap, as a source of glycerine, for manufacturing margarine, cooking fats and

Address for correspondence: James Bamidele, Department of Community Medicine, College of Medicine, Ekiti State University, Ado-Ekiti, Nigeria

E-mail: bjobam2004@yahoo.co.uk

Received: 23 July 2013; accepted: 03 March 2014 for making lubricants. The residue obtained after extraction of the oil is called kernel cake, which is useful in livestock feed production. The crude palm oil (CPO) produced is further processed to yield either red or bleached cooking oil or detergents. The oils are processed from fresh, unbruised fruits, and carefully handled during production, storage and transportation. Palm oil is rich in carotenoids (pigments found in plants and animals) from which it derives its deep red colour; the major component of its glycerides is saturated fatty acid palmitic [2].

The palm oil sub-sector of the agricultural sector of the economy presented itself as a potential productive sector that could be used to diversify the economy because of the numerous economic potentials of palm oil [7]. Ahmed [8] highlighted the importance of the economic tree crop in providing direct employment for about 4 million Nigerians in about 20 oil palm growing states in the country, and to other numerous people involved in its processing and marketing. Agboola [9] was of the opinion that improved technologies that meet both growth and sustainability goals can be effectively used by palm oil processors. Efforts to raise agricultural production and the standard of living of the farmers require the introduction of improved farm equipment and Technologies, as well as increased availability and utilisation of energy and power. However, the great majority of farmers work at near subsistence level of production [10]. Jalani, et al [11] stressed that palm oil processors should embrace a well-integrated capital intensive, high volume and high extraction rate in their processing method in order to encourage the high transformation of the palm oil industry in the country. Unfortunately, the local palm oil processors can hardly afford this. 
Palm oil production is a common occupation among rural dwellers, but despite agricultural mechanization and the introduction of modern tools and equipment for harvesting and processing agricultural products, most Nigerian rural farmers, and especially palm oil farmers, still use the old and crude method for harvesting and processing palm oil. They are thus exposed to various forms of physical, biological, chemical, mechanical and psychosocial hazards that are inherent in all arts and trades, including palm oil processing. For ex ample, during manual harvesting of the palm fruit bunch, a harvester may fall from the palm tree leading to broken legs or even paralysis; injury may be sustained in the form of particles entering the eyes; the spikelet of the palm fruit bunch may pierce the individual; smoke from the fire made during processing of the crude palm oil may affect the eyes and respiratory system; burn injury may occur during the cooking of the fruits or during threshing if leg chopping is used, and burns from the boiling oil extract during the last stage while attempting to separate the edible oil from its entrained impurities. The study by Christe et al [12] shows that hazard analysis and critical control points (or HACCP) has become an internationally- recognized tool for managing the food safety aspect of production, processing, distribution and preparation of palm oil. It is a preventive programme which identifies, accesses and controls hazards which are significant for food safety. However, to what extent the local/traditional palm oil processors are considered in this type of hazard control analysis remains to be seen since the traditional farmers are often not taken into account in the formulation of most government policies and programmes. Occupational and environmental hazards associated with our traditional industries are hardly considered or discussed to provide improved forms for them.

Oil palm is noted to be one of the major cash crops throughout the length and breadth of Delta State, and the indigenes of Delta State use palm oil as a main soup delicacy, and the peasant farmers also market it as a major source of income.

\section{OBJECTIVES}

It is the objective of this study to assess the effect of the occupational hazards of traditional palm oil processing on the health and socio-economic status of rural palm oil processors in Delta State of Nigeria.

\section{MATERIALS AND METHOD}

A cross-sectional analytical study was carried out among rural farmers who are mainly traditional palm oil processors in the Ethiope West Local Government Area (EWLGA) of Delta State in Nigeria. The area is watered by the Ethiope River and its tributaries; most of the land area is flat and swampy with a dense forest growth. Palm trees are the major economic trees found in every part of the land.

The minimum sample size calculated from the target population was 234 respondents, but a total of 295 respondents were finally interviewed using a pretested semi-structured questionnaire. Administration of the questionnaire was by an interview er. There was also an observational check list used for the walk-through survey of the work environment in each of the traditional palm oil processing sites visited. A multistage sampling technique was used. Six of the ten political wards of the EWLGA were selected by the simple random sampling method. In the next stage, each of the palm oil processing sites was taken as a unit, and a cluster sampling of all the available palm oil processors found those who consented to be interviewed in all the six wards. Ethical clearance for the study was obtained from the Ethical Committee of the Delta State University Teaching Hospital, Oghara (DELSUTH), following which a letter of introduction to the Heads of the various communities and wards was given by the Head of the Department of Community Medicine of DELSUTH, Oghara. The researcher and research assistants visited all the wards involved in the survey to carry out community entry and to familiarize thermselves with various farmers' associations. The research assistants were resident doctors; medical students and identified indigenes students of the State Polytechnic sited in the LGA who served as local guides.

The questionnaire had been pretested previously among local palm oil processors in Abraka area which is the site of the Delta State University. The questionnaire elicited information on the social demographic characteristics of the respondents, awareness of the hazards of their job, number of years employed, medical history, and whether they had ever suffered any injury while at work, among others. The survey was carried out over a period of three months from January 2010 - March 2010.

Data analysis was carried out using Statistical Package for Social Sciences (SPSS) version 16. Responses were summarized and presented as frequencies. The odds of experiencing work- related injury for different categories of respondents was estimated using the conditional maximum likelihood estimate of the odds ratio and constructed 95\% confidence limits around the odds ratio using the mid-P exact method.

\section{RESULTS}

A total of 295 respondents participated in the survey. The majority of respondents (39.3\%) were between $21-30$ years of age. The male to female ratio was about 4 to 1 . About two-thirds of respondents were married and $93.2 \%$ were Christians. Urhobo (64.4\%), Isoko (19.3\%), Ijaw (5.8\%) and Itsekiri (3.7\%) were the main tribes in the study area. 127 respondents (43.1\%) had only primary education and 135 (45.8\%) had secondary education (Tab. 1). Respondents had different roles in the traditional palm oil processing activities, ranging from harvesting (34.6\%), fruit sorting (42.0\%), threshing (43.1\%) to extraction (56.6\%). About 4 out of every 10 persons interviewed was engaged in palm oil processing on a permanent basis. Farming was the most frequent additional job that non-permanently engaged persons were involved in. 29 respondents (15.8\%) were attending school in addition to palm oil processing (Tab. 2). The respondents had spent a median of 4.0 years (IQR: 2.0 to 7.0 ) in palm oil processing.

When asked about awareness of occupational hazards in their workplace, only 2 respondents $(0.7 \%)$ provided negative answers. Of those who responded in the affirmative, friends and co-workers accounted for the first source of information for $94.6 \% .293$ respondents were aware of hazards, of whom the majoraty - 271 person $(91.9 \%)$, really considered that 
Table 1. Baseline characteristics of respondents

\begin{tabular}{|c|c|c|}
\hline$n=295$ & Frequency & $\%$ \\
\hline \multicolumn{3}{|l|}{ Age } \\
\hline $11-20$ & 43 & 14.6 \\
\hline $21-30$ & 116 & 39.3 \\
\hline $31-40$ & 90 & 30.5 \\
\hline $41-50$ & 38 & 12.9 \\
\hline $51-60$ & 6 & 2.0 \\
\hline$>60$ & 2 & 0.7 \\
\hline \multicolumn{3}{|l|}{ Gender } \\
\hline Male & 232 & 78.6 \\
\hline Female & 63 & 21.4 \\
\hline \multicolumn{3}{|l|}{ Marital status } \\
\hline Married & 199 & 67.5 \\
\hline Single & 87 & 29.5 \\
\hline Divorced & 2 & 0.7 \\
\hline Separated & 7 & 2.4 \\
\hline \multicolumn{3}{|l|}{ Religion } \\
\hline Christian & 275 & 93.2 \\
\hline Islam & 1 & .3 \\
\hline African tradition religion & 14 & 4.8 \\
\hline Others & 5 & 1.7 \\
\hline \multicolumn{3}{|l|}{ Tribe } \\
\hline Urhobo & 190 & 64.4 \\
\hline Isoko & 57 & 19.3 \\
\hline ljaw & 17 & 5.8 \\
\hline Itsekiri & 11 & 3.7 \\
\hline Others & 20 & 6.8 \\
\hline \multicolumn{3}{|l|}{ Educational status } \\
\hline None & 29 & 9.8 \\
\hline Primary education & 127 & 43.1 \\
\hline Secondary Education & 135 & 45.7 \\
\hline Tertiary Education & 4 & 1.4 \\
\hline
\end{tabular}

Table 2. Job description in oil processing

\begin{tabular}{lcc}
\hline Job description & Frequency & $\%$ \\
\hline Harvesting & 102 & 34.6 \\
\hline Fruit storting & 124 & 42.0 \\
\hline Threshing & 127 & 43.1 \\
\hline Fruit sterilization/cooking & 164 & 55.6 \\
\hline Extraction & 167 & 56.6 \\
\hline Are you permanently employed in oil processing? & & \\
\hline Yes & 111 & 37.6 \\
\hline No & 184 & 62.4 \\
\hline How long have you been in oil processing? & & \\
\hline$<5$ years & 168 & 56.9 \\
\hline$>5$ years & 127 & 43.1 \\
\hline What other work are you involved in? (n=184) & & \\
\hline Farming & 85 & 46.2 \\
\hline Trading & 64 & 34.8 \\
\hline Civil servant & 5 & 2.7 \\
\hline Artisan & 1 & 0.5 \\
\hline Student & 29 & 15.8 \\
\hline
\end{tabular}

Table 3. Awareness of hazards in workplace

\begin{tabular}{lrr}
\hline & Frequency & $\%$ \\
\hline Are you aware of occupational hazards in your work? & & \\
\hline Yes & 293 & 99.3 \\
\hline No & 2 & 0.7 \\
\hline Total & 100.0 \\
\hline If yes, what was your first source of information? ( $\mathbf{n = 2 9 3 )}$ & 6 & 2.0 \\
\hline School & 159 & 54.3 \\
\hline Friends & 118 & 40.3 \\
\hline Co-workers & 6 & 2.0 \\
\hline Health workers & 4 & 1.4 \\
\hline Others & 293 & 100.0 \\
\hline Total & & \\
\hline Do you really believe your occupation is hazardous? & 271 & 91.9 \\
\hline Yes & 24 & 8.1 \\
\hline No & 295 & 100.0 \\
\hline Total & & \\
\hline What are the things that you consider hazardous? (n=271)* & 202 & 74.5 \\
\hline Spikelet injury & 182 & 67.2 \\
\hline Burn injury & 82 & 30.3 \\
\hline Snake bite injury & 89 & 32.8 \\
\hline Smoke injury & 68 & 25.1 \\
\hline Bee sting injury & \\
\hline
\end{tabular}

*multiple responses allowed

Table 4. Awareness of hazard prevention measures

\begin{tabular}{lrr}
\hline & Frequency & $\%$ \\
\hline $\begin{array}{l}\text { Are there protective measures that can be used to } \\
\text { prevent these hazards? }\end{array}$ & & \\
\hline Yes & 243 & 89.7 \\
\hline No & 3 & 1.1 \\
\hline Don't know & 6 & 2.2 \\
\hline No response & 19 & 7.0 \\
\hline Total & 271 & 100.0 \\
\hline
\end{tabular}

In general terms, how do you think hazards can be

prevented? $(\mathbf{n}=295)^{*}$

\begin{tabular}{lrr}
\hline Making sure that hazards do not occur at all & 282 & 95.6 \\
\hline Going for treatment when the hazard has already occurred & 128 & 43.4 \\
\hline Reducing hazards to the minimum & 178 & 60.3 \\
\hline Periodic monitoring of your health status & 166 & 56.3 \\
\hline General hygiene of working environment & 246 & 83.4 \\
\hline Use of safety devices, like shoe boots, gloves, overall & 264 & 89.5 \\
\hline $\begin{array}{l}\text { Elimination of hazardous agent by substitution with less } \\
\text { hazardous ones }\end{array}$ & 87 & 29.5 \\
\hline Which hazard prevention tools are available for your use? & & \\
\hline Boot & 70 & 23.7 \\
\hline Hand Glove & 142 & 48.2 \\
\hline Helmet & 16 & 5.4 \\
\hline Work clothes/protective wear & 67 & 22.7 \\
\hline
\end{tabular}

${ }^{*}$ multiple responses allowed

their occupation was hazardous. Spikelet and burn injuries were reported by most respondents as the real hazards faced (Tab. 3). About $89.7 \%$ were aware of preventive measures for reported hazards. Hand gloves (48.2\%), boots (23.7\%), work clothes/protective wears (22.7\%) and helmets (5.4\%) were the only personal protective equipment reported as being available (Tab. 4). 
Table 5. Experience of injury and illness

\begin{tabular}{|c|c|c|}
\hline & Frequency & $\%$ \\
\hline \multicolumn{3}{|c|}{ Have you suffered any injury while at work $(n=295)$} \\
\hline Yes & 230 & 78.0 \\
\hline No & 65 & 22.0 \\
\hline \multicolumn{3}{|c|}{ If yes, what was the cause of injury? $(n=230)^{*}$} \\
\hline Spikelet injury & 182 & 79.1 \\
\hline Burn injury & 57 & 24.8 \\
\hline Fall & 38 & 16.5 \\
\hline Cutlass injury & 18 & 7.8 \\
\hline Smoke irritation & 111 & 48.3 \\
\hline Presser injury & 14 & 6.1 \\
\hline Bee sting & 13 & 5.7 \\
\hline Snake bite & 2 & 0.9 \\
\hline \multicolumn{3}{|c|}{ Do you think the injury could have been prevented? $(n=230)$} \\
\hline Yes & 191 & 83.0 \\
\hline No & 39 & 17.0 \\
\hline \multicolumn{3}{|c|}{$\begin{array}{l}\text { Have you suffered any illness/disease in the past } 12 \text { months more than } \\
\text { once? }(n=295)\end{array}$} \\
\hline Yes & 67 & 22.7 \\
\hline No & 228 & 77.3 \\
\hline \multicolumn{3}{|c|}{ If yes, state the conditions suffered from $(n=67)$} \\
\hline Cough & 16 & 23.8 \\
\hline Neck pain & 5 & 7.5 \\
\hline Eye Itching & 5 & 7.5 \\
\hline Malaria & 35 & 52.2 \\
\hline Low back pain & 6 & 9.0 \\
\hline
\end{tabular}

Table 6. Relationship between awareness, duration at work and experience of work-related injury

\begin{tabular}{|c|c|c|c|c|c|}
\hline \multirow[t]{2}{*}{ Yes } & & \multicolumn{2}{|c|}{$\begin{array}{l}\text { Have you suffered any } \\
\text { injury while at work? }\end{array}$} & \multirow[t]{2}{*}{ Total } & \multirow{2}{*}{$\begin{array}{l}\text { Odds ratio* } \\
(95 \% \mathrm{Cl})^{* *}\end{array}$} \\
\hline & & No & & & \\
\hline \multirow{2}{*}{$\begin{array}{l}\text { Are you aware } \\
\text { of occupational } \\
\text { hazards? }\end{array}$} & Yes & 228 (77.8\%) & 65 (22.2\%) & $293(100.0 \%)$ & \multirow{2}{*}{$\begin{array}{l}-0.7 \\
(0.0,11.51)\end{array}$} \\
\hline & No & $2(100.0 \%)$ & $0(0.0 \%)$ & $2(100.0 \%)$ & \\
\hline \multirow{2}{*}{$\begin{array}{l}\text { Do you really } \\
\text { believe your } \\
\text { occupation is } \\
\text { hazardous? }\end{array}$} & Yes & 213 (78.6\%) & $58(21.4 \%)$ & $271(100.0 \%)$ & \multirow[b]{2}{*}{$\begin{array}{l}1.51 \\
(0.56,3.76)\end{array}$} \\
\hline & No & $17(70.8 \%)$ & $7(29.2 \%)$ & 24 (100.0\%) & \\
\hline \multirow{2}{*}{$\begin{array}{l}\text { Duration at } \\
\text { work }\end{array}$} & $\begin{array}{l}<5 \\
\text { years }\end{array}$ & 130 (77.4\%) & $38(22.6 \%)$ & 168 (100.0\%) & \multirow{2}{*}{$\begin{array}{l}0.92 \\
(0.52,1.62)\end{array}$} \\
\hline & $\begin{array}{l}>5 \\
\text { years }\end{array}$ & 100 (78.7\%) & $27(21.3 \%)$ & 127 (100.0\%) & \\
\hline Total & & 230 (78.0\%) & $65(22.0 \%)$ & 295 (100.0\%) & \\
\hline
\end{tabular}

*Conditional maximum likelihood estimate of Odds Ratio

${ }^{* *}$ Mid-P exact

As many as $78.0 \%$ of all respondents had experienced an injury while at work, ranging from spikelet injury $(79.1 \%)$ to snake bites $(0.9 \%)$. The majority $(83.0 \%)$ of those who had suffered an injury felt that it could have been prevented. On the contrary, $22.7 \%$ had experienced an illness while at work in the past twelve months prior to the study (Tab. 5). The experience of a work-related injury occurred more frequently among those who were aware of the occupational hazards they faced. Those who believed that the occupation was hazardous were about twice more likely to have experienced a work-related injury; while a shorter duration ( $<5$ years) at work was associated with fewer experiences of work-related injury. Not All these estimates, however, were significant, as the confidence intervals included the point of no difference (Tab. 6).

\section{DISCUSSION}

Palm oil is the most important source of vegetable oil of all oil-bearing plants and Has the highest yielding. Palm oil production is a common occupation among rural dwellers. Various steps in the oil processing can be associated with hazards if safety measures are not properly taken. Palm oil processing with the indigenous technology, which is mainly a women's occupation at the village level in Akamili, Nnewi, Anambra State, Nigeria, was assessed with the hazard analysis and critical control points (HACCP) system for food safety and quality. The analysis showed that hazards existed at all stages of the process [13].

The presented study investigated the prevailing occupational hazards and their effects on the socio-economic and health status of traditional palm oil processors in the Ethiope West Local Government Area of Delta state In Nigeria. The age group of about $40 \%$ of the respondents was $21-30$ years and might be the reason why more thana half of the respondents have spent less than five years on the job as palm oil processors. There were more males than females (ratio 4:1) who participated in the survey. This is similar to the study among oil palm famers in the Ife area in Osun State, Nigeria, where the majority (79.4\%) of respondents were males, while about $21 \%$ were females [14]. In the current study, more than half of the respondents had only primary education or no education at all. About $40 \%$ are engaged in palm oil processing on a permanent basis. They use bare hands in harvesting, fruit storting, and use leg chopping during threshing, and fruit sterilization/cooking is carried out on fires. These were witnessed during the walk- through survey in most of the palm oil processing sites visited, all of which confirmed the fact that they are peasant farmers who practice manual oil processing because they are poor. This is also corroborated by studies among oil palm processors in the Egbedore and Ife areas of Osun State where the majority of farmers adopted traditional processing methods because they were poor and cannot afford a hand-operated Press. Hence the output at a single processing would always be minimal since it involved only manual labour $[14,15]$.

Over $60 \%$ of the respondents are engaged in other jobs, including farming and trading, because traditional palm oil processing alone could not sustain them and their families. This is different from the findings of the study on palm oil and economic development in Africa [16] which claimed that an average palm oil producer lives well above the poverty line. The difference must have been because the study targeted a few organized private and public holding plantations as against the rural palm oil processors, as in the case of the presented study.

Of those who are aware of hazards of their occupation, over $90 \%$ percent have their friends and co-workers as their source of information regarding hazards inherent in palm oil processing. Of this number, nine out of every ten of them consider their occupation as hazardous. Despite the majority being aware of the hazards of their occupation, as many as $78.0 \%$ have suffered various forms of injury at work. This means awareness of occupational hazards did not have any relationship with experience of work-related injury. The local palm oil processors in this study mostly experienced spikelet 
injury and smoke irritation; other injuries include burns, falls, presser injury, bee stings and snake bites. In a study among palm oil processors in Ghana, cuts (35.0\%), burns (33.0\%), oil splashes (26.0\%) were the major injuries encountered during work [17]. In the current study, further analysis showed that those who believe that the occupation was hazardous were about twice more likely to have experienced a work-related injury. This might be because most of the workers were aware of hazards after they had actually experienced some form of injury. This is exactly at variance with an earlier assertion that all workmen should be told something of the material with which they come into contact, and not left to find it out for themselves - sometimes at the cost of their lives [18]. Also, a shorter duration ( $<5$ years) at work was associated with fewer experiences of work-related injury, meaning that the local palm oil processors in this study are constantly exposed to occupational hazards Since the majority do not use protective devices, and continue to process palm oil manually.

As many as every nine out of ten respondents agreed that there are protective measures that can be used to prevent the hazards emanating from their job. Also, 95.6\%, 83.4\% and $89.5 \%$ think hazards can be prevented by making sure that hazards do not occur at all, that there should be general hygiene in the work place, and by using safety devices, respectively. However, these assertions do not translate to workers practices, as less than half of the respondents use hand gloves and less than a quarter wear boots and protective wears, respectively.

The walk-through survey of the local palm oil processing sites revealed poor hygiene practices among this group of Wolkers, with open dumping and indiscriminate display of palm fruits and other work materials being the order of the day. Ego [13], in his study, also reported points of microbial infection and contamination with sand particles, rusty and dirty baskets, head pans or wheel barrows, tins, transparent bottles and plastic jars on the floor, dirty mortar/pestles and a generally dirty environment in the palm processing sites surveyed.

The medical histories of the respondents for the twelve months prior to the study revealed that about a quarter of them have suffered illnesses, especially malaria (52.0\%) and cough (23.8\%). Other illnesses suffered include low back pain (9.0\%), neck pain (7.5\%) and eye itching (7.5\%). A Ghana study also quoted sicknesses often reported as: eye problems (21.5\%), breathing problems $(17.7 \%)$, headache $(17.7 \%)$, coughing (12.7\%) and malaria (10.1\%) [17]. Previous studies have reported that low back pain is a prevalent health problem among rural peasant farmers. The reported level of low back pain, although low in this study probably because of focusing on only one group of peasant farmers, further confirms the results of earlier studies of low back pain: $72.4 \%, 67.1 \%$ and $40.0 \%$ among farmers in Iju-Odo, South West, Ebubu Community in the south and in another rural community in sout-western Nigeria, respectively. $[19,20,21]$ The other illnesses reported confirm that the palm oil processors in this study area also suffer from the common illnesses affecting the general population.

\section{CONCLUSION}

The presented study has revealed that the rural palm oil processors in the study area are socio-economically poor and are engaged in manual palm oil processing using their bare hand and crude tools. They suffer from various forms of occupational injuries relevant to their trade, and suffer from illnesses directly relating to their occupational exposure, apart from the illnesses suffered by the general population.

It is strongly recommended that local/traditional palm oil processors are considered when implementing any form of hazard control analysis, and be taken into account in the formulation of most government policies and programmes. Occupational and environmental hazards associated with our traditional industries should be considered or discussed to provide an improved form for them.

\section{REFERENCES}

1. Rahman AAA. Malaysian Oil Palm Industry. Retrospect and Prospect. International Oil Palm Conference, 1998, Indonesia.

2. Small-scale Palm Oil Processing in Africa. Corporate Document Repository. FAO; 2005 www.fao.org/Docrep/05/YE335E/Y4355e03. htm (access: 2013.07.23).

3. Carrer R. Over view of the oil Palm Issues. World Rainforest Movement, Uruguay, 2001.pp.1-16.

4. Anyawu AC, Anyawu BO, Anyawu VA. A Textbook of Agriculture for School Certificate. 4th Edition, Nsukka, Nigeria: Africana Educational Publishers Ltd., 1982.

5. Bockish M. Fats and Oils Handbook. AOCS Press, 1998.

6. Adegbola AA, Are LA, Ashaye TI, Komolafe MF. Agricultural Science for West African Schools and Colleges. Oxford University Press, Ibadan, Nigeria, 1979.

7. Purvis JM. New Sources of Growth in a Stagnant Smallholder Economy in Nigeria in Growth and Development of the Nigerian Economy. Eicher CK, Liedholm (eds.). Michigan State University Press, 1970.

8. Ahmed SA. Agriculture and Food Security in Nigeria. Paper presented for a forum with Mr. President on Agriculture and Food Security Council Chambers Presidential Villa. Abuja, 2001.

9. Agboola AA. Farming systems in Nigeria. In fundamentals of Agriculture. Edited by Aiyelari EA, Abatan MO, Lucas EO, Akinboade OA, 1993.

10. Cobezas M, Emhardt F, Kutzbach H. Convertible Equipment for Oxen carts. Working paper series 2. Special Research Programme 308, University of Hohenheim, 1995.

11. Jalani BS, Ariffion D, Chan KW. Malaysia's contribution to improving the value and use of palm oil through moderm technologies in Burotrop. Bulletin 2003; 19: 25.

12. Christie F. Robert and Sathianathan Menon. Improving the Environmental Sustainability and the Export Competitiveness in the Food Sector: Case of the Malaysian palm oil industry 2006; 1-33.

13. Ego U. Okonkwo. Hazard analysis and critical control points in palm oil processing in Anambra State, Nigeria. African Journal of Agricultural Research 2011; 6(2): 244-247.

14. Soyebo KO, Farinde AJ, and Dionco-Adetayo ED. Constraints of Oil Palm Production in Ife Central Local Government Area of Osun State, Nigeria. J Soc Sci. 2005; 10(1): 55-59.

15. Oke OE. Evaluation of Palm Oil Processing in Egbedore Local Government Area of Osun State, Nifgeria. Ile Ife, Nigeria: Obafemi Awolowo University, 2002.

16. Ayodele T. Initiative for Public Policy Analysis. African Case Study: Palm Oil and Economic Development in Nigeria and Ghana. Recommendations for the World Bank's 2010 Palm Oil Strategy www. ippanigeria.org/worldbankreportpalmoil (access: 2013.07.23).

17. Michael AA, Kwasi OB. Occupational hazards and environmental health associated with the traditional palm kernel oil extraction method. Der Chemica Sinica. 2013; 4(3): 114-121.

18. Asogwa SE. A Guide to Occupational Health Practice in Developing Countries. 3rd ed. Snaap Press, Enugu, 2007.p. 1-10.

19. Fabunmi AA, Aba SO, Odunnaiya NA. Prevalence of low back pain among peasant farmers in a rural community in South West, Nigeria. Afr J Med Sci. 2005; 34(3): 259-262.

20. Birabi BN, Dienye PO, Nduku GU. Prevalence of Low Back Pain among peasant farmers in a rural community in South-South, Nigeria. Rural Remote Health 2012; 12: 1920.

21. Omokhodion FO. Low back pain in a rural Community in South West Nigeria. West Afr J Med. 2002; 21(2): 87-90. 